\title{
$\beta$-Hydrosilylation of Allylic Derivatives with Cyclic and Linear Siloxanes in the Presence of Platinum Catalysts
}

\author{
Zainab Rbihi1, Salah Eddine Lanaya1,2, Mohamed Yassine Guida1, El Mostapha Rakib1, \\ Abdelatif Barakat ${ }^{2}$, Abdelghani El Malki ${ }^{1}$, Abdellah Hannioui ${ }^{*}$ \\ ${ }^{1}$ Laboratoire de Chimie Organique et Analytique, Université Sultan My Slimane, Faculté des Sciences et Techniques, Béni-Mellal, \\ Morocco \\ ${ }^{2}$ INRA, UMR IngnAgropolymeres \& Technol Emergentes 1208, 2 Pl Pierre Viala, F-34060 Montpellier, France \\ Email: *hannioui15@yahoo.fr
}

How to cite this paper: Rbihi, Z., Lanaya, S.E., Guida, M.Y., Rakib, E.M., Barakat, A., El Malki, A. and Hannioui, A. (2021) $\beta$-Hydrosilylation of Allylic Derivatives with Cyclic and Linear Siloxanes in the Presence of Platinum Catalysts. Open Access Library Journal, 8: e7364.

https://doi.org/10.4236/oalib.1107364

Received: March 29, 2021

Accepted: April 27, 2021

Published: April 30, 2021

Copyright $\odot 2021$ by author(s) and Open Access Library Inc.

This work is licensed under the Creative Commons Attribution International License (CC BY 4.0).

http://creativecommons.org/licenses/by/4.0/

\begin{abstract}
The aim of this work is to study the influence of the nature and position of substitution at allyl benzene on the regioselectivity of the hydrosilylation reaction. We studied hydrosilylation of the various allyl derivatives with cyclic siloxane, $\mathrm{D}_{4}^{\mathrm{H}}$, and linears hydrosilylating agents, 1,1,3,3-tetramethyldisiloxane and $\mathrm{MD}^{\mathrm{H}} \mathrm{M}$, in the presence of platinum-based catalysts (Karstedt catalyst, platinum black). We also show the effects of the amount of catalyst on the conversion. Moreover, the influence on the temperature on catalytic activity and selectivity of the hydrosilylation reaction was explained. All new compounds were characterized by ${ }^{1} \mathrm{H},{ }^{13} \mathrm{C},{ }^{29} \mathrm{Si}$ NMR and HRMS as well.
\end{abstract}

\section{Subject Areas \\ Organic Chemistry}

\section{Keywords}

Allylbenzene Derivatives, Karstedt's-Catalyst, Hydrosilylation, Siloxane $D_{4}^{\mathrm{H}}$, Platinum Black

\section{Introduction}

An important and well-known class of polymers is represented by silicones [1] [2] [3]. Several methods are known to produce organo functional silanes. One of the most frequently used is the transition metal catalysed hydrosilylation of olefins bearing functional groups [4] [5] [6] [7]. Hydrosilylation reactions are gen- 
erally carried out in the presence of platinum catalyst [8].

Very few siloxanes resulting from a selective $\beta$-addition of $\mathrm{D}_{4}^{\mathrm{H}}$ and linear hydrosilylating agent to the double bond of terminal olefins functionalized in the allylic position have been prepared to date. One interesting example is the quantitative $\beta$-hydrosilylation of the allyl alcohol with $\mathrm{D}_{4}^{\mathrm{H}}$ described by Zhang and Laine [9]. In the other cases, characterization of reactions products seemed to be difficult [9].

We reported previously [10], the hydrosilylation conditions to obtain the product $\beta$ and minimized the by-products (isomerization, hydrogenation) of this reaction, it was found that the use of $1 \times 10^{-5}$ mole cat./mole olefin for the Karstedt catalyst or $1 \times 10^{-3}$ mole cat./mole olefin for the platinum black at $40^{\circ} \mathrm{C}$ allows the reaction to be carried out in a highly regioselective manner $(100 \%$ of the $\beta$ isomer).

Igarashi and al. [11], studied the hydrosilylation reactions of allyl derivatives with hydrosilanes (2,4,6,8-tetramethyl-cyclotetrasiloxane $\left.\mathrm{D}_{4}^{\mathrm{H}}\right)$. These were carried out in the presence of the Karstedt's catalyst in order to compare their structure-reactivity relationship, but the reaction was in selective with low yield (between 50\% - 70\%).

In this paper, we wish to report our results on the hydrosilylation of the substituted allylbenzene with $\mathrm{D}_{4}^{\mathrm{H}}$ and linears hydrosilylating agents, 1,1-3,3-tetramethyl-disiloxane and $\mathrm{MD}^{\mathrm{H}} \mathrm{M}$ in the presence of platinum catalysts. The choice of platinum catalysts used in this research for the hydrosilylation reaction is platinum (0)-1,3-divinyl-1,1,3,3-tetramethyldisiloxane complex solution or also known as Karstedt's catalyst and platinum black. Also, the influence of substitution of allyl benzyl derivatives at different positions, amount of catalyst and reaction temperature on regioselectivity was studied.

\section{Results and Discussion}

Initially, the substituted allylbenzenes 1 (1.1 equiv.) were reacted with $\mathrm{D}_{4}^{\mathrm{H}} \quad(1.0$ equiv.), using $1 \times 10^{-5}$ mole of Karstedt's catalyst/mole olefin or $1 \times 10^{-3}$ mole of platinum black/mole of olefin in dry toluene at temperatures $40^{\circ} \mathrm{C}$ and $90^{\circ} \mathrm{C}$ for 3 hours, a reaction leading to the hydrosilylated products 3 and 4 took place. These latter could be isolated in excellent yields and good purity just by bulb to bulb elimination under high vacuum at $100^{\circ} \mathrm{C}$ of the isomerized olefins (usually $3 \%$ to $11 \%)$ and traces $(\leq 1 \%)$ of the reduced compound. Neither the $2160 \mathrm{~cm}^{-1}$ $\mathrm{Si}-\mathrm{H}$ infrared band norits ${ }^{1} \mathrm{H}$ NMR peak at $4.61 \mathrm{ppm}$ was detectable in the finalcrude product. Results are reported in Table 1.

The results indicate that the Karsted' catalyst shows excellent catalytic performance for the hydrosilylation of Allylbenzene derivatives. The conversion of Allylbenzene reaches up to $96 \%$ with a higher than $99 \% \beta$-adduct selectivity (entry 1, Table 1). Meanwhile, $94 \%$ conversion of Allylbenzene with $98.3 \%$ selectivity for the $\beta$-adduct was obtained under the similar conditions when platinum black was used (entry 2 , Table 1 ). 
Table 1. Hydrosilylation of alkenes catalyzed by Pt.

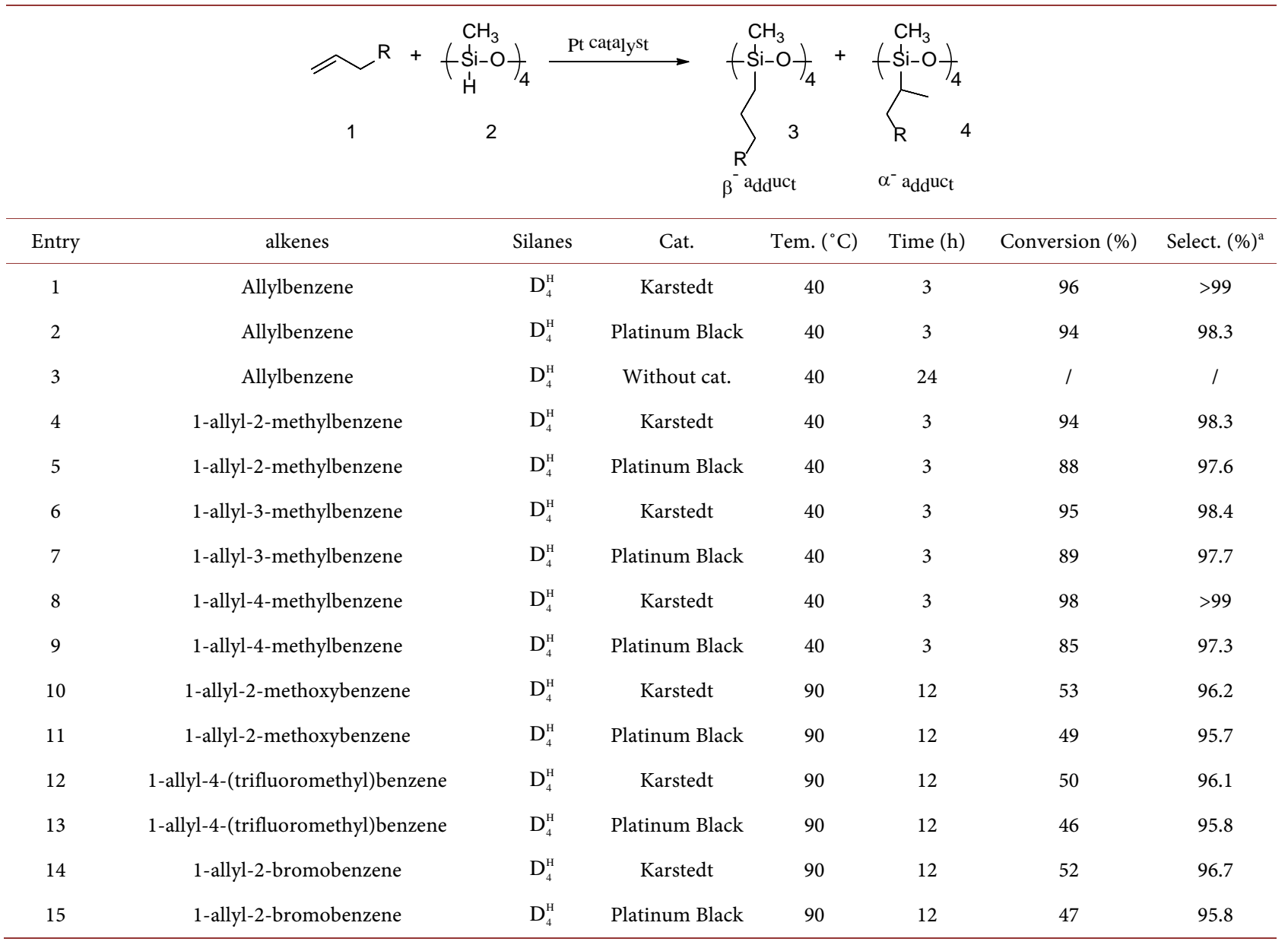

Reaction condition: allylbenzene $18.2 \mathrm{mmol}, \mathrm{D}_{4}^{\mathrm{H}} 4.13 \mathrm{mmol}$, Karstedt $10^{-5} \mathrm{~mol}$ of Pt/mole of olefin and $1 \times 10^{-3} \mathrm{~mole}$ of Pt/mole of olefin for platinum

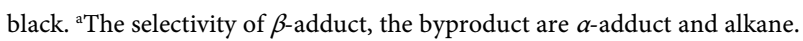

On the other hand, the conversion of 1-allyl-4-methylbenzene is increased to $98 \%$ when $1 \times 10^{-5}$ mole of Karstedt's catalyst/mole olefin was used. The conversion of 1-allyl-4-(trifluoromethyl)benzene reaches up to $50 \%$ and $46 \%$ with 96.1\% and $95.8 \% \beta$-adduct selectivity with Karstedt's catalyst and platinum black respectively (entry 12 , Table 1 ). The reactivity of this olefin is low for platinum catalyst due to the steric effect.

\subsection{Effect of Amount of Pt on Hydrosilylation of Allylbenzene}

The effect of the amount of catalyst on the conversion of allylbenzene is illustrated in Table 2. It can be seen that higher conversion is obtained when was used low quantity of catalyst during the same reaction time. $85 \%$ conversion with $99.7 \%$ selectivity of $\beta$-adduct is obtained by using $3 \times 10^{-5} \mathrm{~mol}$ catalyst $/ \mathrm{mol}$ of olefin, however, the better selectivity is attained by using lower amount of catalyst (i.e. $10^{-5} \mathrm{~mol} \mathrm{Karstedt} \mathrm{and} 10^{-3} \mathrm{~mol}$ Platinum Black catalysts/mol of olefin). The more catalyst leaded to generating propylebenzene through hydrogenation of allylbenzene. Similar results were found when X. Yang and co-workers used 
Table 2. Effect of amount of Pt-catalyst on hydrosilylation of Allylbenzene.

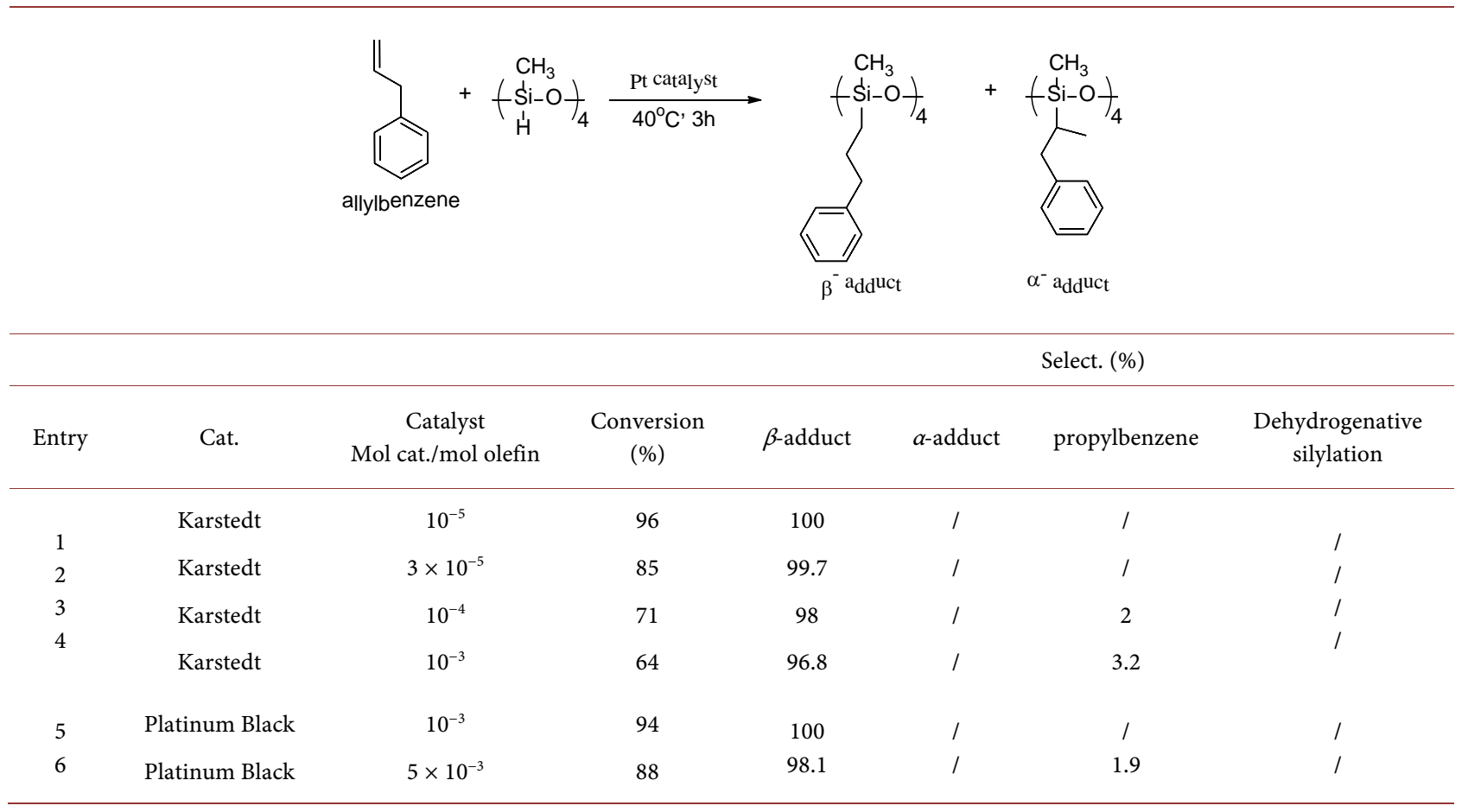

Reaction condition: allylbenzene $18.2 \mathrm{mmol}, \mathrm{D}_{4}^{\mathrm{H}} \quad 4.13 \mathrm{mmol}, 40^{\circ} \mathrm{C}, 3 \mathrm{~h}$.

iron as a catalyst [12].

\subsection{Effect of Reaction Temperature on the Hydrosilylation}

The effect of temperature on catalytic activity and selectivity of the hydrosilylation reaction is shown in Figure 1 (using Speier's catalyst as an example). With the increase of temperature, the time needed for $100 \%$ styrene conversion $(t 100)$ is shortened, while the selectivity for the $\beta$-adduct is kept at around $100 \%$. This indicates that the temperature promotes the catalytic activity but has only a slight influence on the $\beta$-adduct selectivity (Figure 1(b)).

Indeed, the effect of reaction temperature on the catalytic activity was investigated and the results are illustrated in Table 3. It indicates that the activity of the Karstedt and platinum black is higher at $40^{\circ} \mathrm{C}$. Using the same amount of catalyst, the conversion of the substrate is between $71 \%$ and $79 \%$ at $90^{\circ} \mathrm{C}$ after $3 \mathrm{~h}$. When the temperature is $40^{\circ} \mathrm{C}$, the conversion of Allylbenzene is between 94 and $96 \%$ within $3 \mathrm{~h}$.

\subsection{Hydrosilylation of Allylbenzene with Various Silanes}

Under similar conditions, different silanes were used (Table 4). The conversion of Allylbenzene is $96 \%, 94 \%$ and $90 \%, 87 \%$ (Karstedt', platinum black) when $\mathrm{D}_{4}^{\mathrm{H}}$ and $\mathrm{MD}^{\mathrm{H}} \mathrm{M}$ were used, respectively. The corresponding selectivity of $\beta$-adduct is $100 \%$. Tetramethyl disiloxane gave the conversion $72 \%$ and $71 \%$ with high selectivity of $\beta$-adduct, is $100 \%$. 


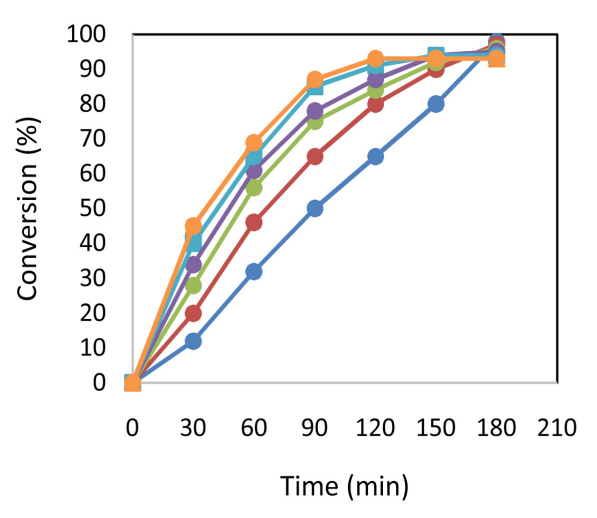

(a)

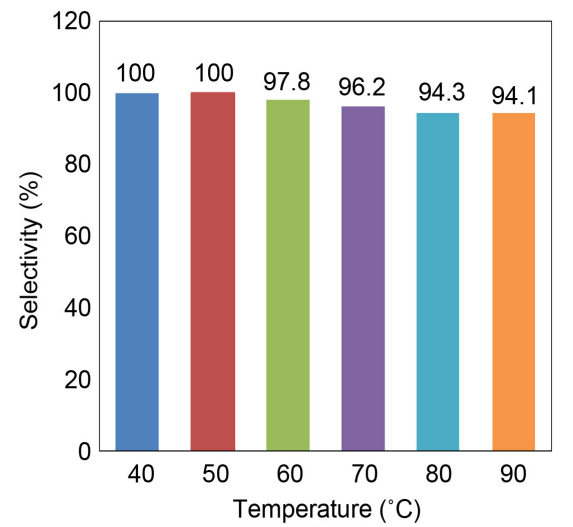

(b)

Figure 1. Effect of temperature on the hydrosilylation reaction of allylbenzene: (a) catalytic activity and (b) selectivity to $\beta$-adduct.

Table 3. Effect of temperature on the hydrosilylaiton of Allylbenzene with $\mathrm{D}_{4}^{\mathrm{H}}$.

\begin{tabular}{|c|c|c|c|c|c|c|c|}
\hline \multirow[b]{2}{*}{ Entry } & \multirow[b]{2}{*}{ Cat. } & \multirow[b]{2}{*}{ Temp. $\left({ }^{\circ} \mathrm{C}\right)$} & \multirow[b]{2}{*}{ Conversion (\%) } & \multicolumn{4}{|c|}{ Select. (\%) } \\
\hline & & & & $\beta$-adduct & $\alpha$-adduct & propylbenzene & Dehydrogenative silylation \\
\hline 1 & Karstedt & 20 & No reaction & 1 & l & 1 & I \\
\hline 2 & Platinum black & 20 & No reaction & l & l & I & I \\
\hline 3 & Karstedt & 40 & 96 & 100 & I & I & I \\
\hline 4 & Platinum black & 40 & 94 & 100 & l & I & I \\
\hline 5 & Karstedt & 50 & 91 & 100 & l & l & I \\
\hline 6 & Platinum black & 50 & 89 & 100 & I & / & I \\
\hline 7 & Karstedt & 60 & 88 & 97.8 & l & 2.2 & l \\
\hline 8 & Platinum black & 60 & 85 & 94.2 & I & 5.8 & I \\
\hline 9 & Karstedt & 70 & 83 & 96.2 & l & 3.8 & I \\
\hline 10 & Platinum black & 70 & 79 & 91.8 & I & 8.2 & I \\
\hline 11 & Karstedt & 80 & 80 & 94.3 & I & 5.7 & I \\
\hline 12 & Platinum black & 80 & 75 & 89 & I & 11 & I \\
\hline 13 & Karstedt & 90 & 79 & 94.1 & I & 5.9 & I \\
\hline 14 & Platinum black & 90 & 71 & 81.3 & I & 18.7 & I \\
\hline
\end{tabular}

Reaction condition: allylbenzene $18.2 \mathrm{mmol}, \quad \mathrm{D}_{4}^{\mathrm{H}} 4.13 \mathrm{mmol}$. (0.3 $\mu \mathrm{l}$ of $10^{-5} \mathrm{~mol}$ of Pt/mole of olefin for Karstedt's catalyst) and $\left(0.244 \mathrm{~g}, 1 \times 10^{-3} \mathrm{~mole}\right.$ of $\mathrm{Pt} /$ mole of olefin for platinum black), $3 \mathrm{~h}$.

Table 4. Scope of silane for Pt catalyzed hydrosilylation of Allylbenzene.

\begin{tabular}{|c|c|c|c|c|c|c|c|}
\hline \multirow[b]{2}{*}{ Entry } & \multirow[b]{2}{*}{ Cat. } & \multirow[b]{2}{*}{ Silane } & \multirow[b]{2}{*}{ Conversion (\%) } & \multicolumn{4}{|c|}{ Select. (\%) } \\
\hline & & & & $\beta$-adduct & $\alpha$-adduct & propylbenzene & Dehydrogenative silylation \\
\hline 1 & Karstedt & $\mathrm{D}_{4}^{\mathrm{H}}$ & 96 & 100 & l & I & / \\
\hline 2 & Platinum black & $\mathrm{D}_{4}^{\mathrm{H}}$ & 94 & 100 & I & 1 & I \\
\hline 3 & Karstedt & Tetramethyl disiloxane & 72 & 100 & / & 4.1 & 24.9 \\
\hline 4 & Platinum black & Tetramethyl disiloxane & 71 & 100 & I & 4.3 & 24.7 \\
\hline 5 & Karstedt & $\mathrm{MD}^{\mathrm{H}} \mathrm{M}$ & 90 & 100 & l & 1 & I \\
\hline 6 & Platinum black & $\mathrm{MD}^{\mathrm{H}} \mathrm{M}$ & 87 & 100 & I & I & / \\
\hline
\end{tabular}

Reaction condition: allylbenzene $18.2 \mathrm{mmol}, \mathrm{D}_{4}^{\mathrm{H}} 4.13 \mathrm{mmol}$. For Karstedt $\left(0.3 \mu \mathrm{l}, 10^{-5} \mathrm{~mol}\right.$ of cat./mole of olefin) and $\left(0.244 \mathrm{~g}, 1 \times 10^{-3} \mathrm{~mole}\right.$ of Pt $/ \mathrm{mole}$ of olefin) for platinum black, $40^{\circ} \mathrm{C}, 3 \mathrm{~h}$.

\section{Conclusion}

In summary, we have developed a simple and easy method to synthesize func- 
tionalized siloxanes by $\mathrm{D}_{4}^{\mathrm{H}}, \mathrm{MD}^{\mathrm{H}} \mathrm{M}$ and 1,1-3,3-tetramethyldisiloxane with a high regioselectivity. Karstedt's-catalyst appeared to be most efficient. The same kind of reactivity and selectivity was observed with black platinum, although 100 times more catalyst was used. The nature of substituents on the aromatic ring or the hydrosilylating agent has a little influence on the $\beta / \alpha$ ratio. However, the amount of catalyst and reaction temperature appeared to be more important.

\section{Experimental Method}

All chemical reagents were commercially available. Toluene was distilled from sodium benzophenone ketyl immediately prior to use, platinum (0)-1,3-divinyl1,1,3,3-tetramethyldisiloxane complex solution (Karstedt's catalyst, $\mathrm{Pt} \sim 2 \%$ in xylene), 2,4,6,8-tetramethylcyclotetrasiloxane ( $D_{4}^{\mathrm{H}} \geq 99.5 \%$ and $\geq 99.999 \%$ trace metals analysis). All other chemicals were used as received without further purification. All manipulations involving air-sensitive species were carried out in Schlenk apparatus under dry nitrogen. ${ }^{1}$ H.n.m.r. ${ }^{13} \mathrm{C}$ and ${ }^{29} \mathrm{Si}$ spectra were recorded on a Brucker type device 500, 125 and $99 \mathrm{MHz}$ instrument with $\mathrm{CDCl}_{3}$ as the solvent; the chemical shifts were reported in ppm, by reference to $\mathrm{Me}_{4} \mathrm{Si}$. the coupling constants $(\mathrm{J})$ are expressed in Hertz $(\mathrm{Hz})$.

\section{Experimental Procedures}

a) Preparation of

1,3,5,7-tetra-(3-(phenyl)propyl)-1,3,5,7-tetramethyl-cyclotetrasiloxane (3a) from allylbenzene with $D_{4}^{H}$ in the presence of Karstedt's catalyst is representative.

The Solution of allylbenzene $(2.4 \mathrm{ml}, 18.2 \mathrm{mmol})$ and Karstedt's catalyst $(0.3$ $\mu \mathrm{l}$ of a $0.336 \mathrm{~mol} / \mathrm{l}$ solution of $\mathrm{Pt} / \mathrm{mole}$ of olefin) in toluene $(5 \mathrm{ml})$ was warmed to $40^{\circ} \mathrm{C}$ under argon. $\mathrm{D}_{4}^{\mathrm{H}}(1 \mathrm{ml}, 4.13 \mathrm{mmol})$ was added slowly and subsequently heated at To this stirred solution wich was subsequently heated at $40^{\circ} \mathrm{C}$ for $3 \mathrm{~h}$. the hydrosilylation was followed by ${ }^{1} \mathrm{H}$ NMR and the reaction stopped once the $\mathrm{Si}-\mathrm{H}$ signal has disappeared. The solvent was then evaporated under reduced pressure. Volatile by-products and excess of olefin were removed by bulb to bulb distillation $\left(100^{\circ} \mathrm{C}, 0.01\right.$ torr $)$.

1,3,5,7-tetra-(3-(phenyl)propyl)-1,3,5,7-tetramethyl-cyclotetrasiloxane was obtained as viscous oil in a $96 \%$ yields.

b) Preparation of

1,3,5,7-tetra-(3-(phenyl)propyl)-1,3,5,7-tetramethyl-cyclotetrasiloxane (3a) from allylbenzene with $D_{4}^{\mathrm{H}}$ in the presence of platinum black is representative.

A solution of allylbenzene $(2.4 \mathrm{ml}, 18.2 \mathrm{mmol})$ and platinum black $(0.244 \mathrm{~g}$, $1 \times 10^{-3}$ mole of $\mathrm{Pt} / \mathrm{mole}$ of olefin) in toluene $(5 \mathrm{ml})$ was warmed to $40^{\circ} \mathrm{C}$. To this stirred solution, $\mathrm{D}_{4}^{\mathrm{H}} \quad(1 \mathrm{ml}, 4.13 \mathrm{mmol})$ was added slowly and subsequently heated at $40^{\circ} \mathrm{C}$ for $3 \mathrm{~h}$. After filtration over glass wool, the solvent was evaporated under reduced pressure; volatile by-products and excess of olefin were re- 
moved by bulb to bulb distillation $\left(100^{\circ} \mathrm{C}, 0.01\right.$ torr $)$.

c) Preparation of

1,3-di-(3-(phenyl)propyl)-1,1,3,3-tetramethyl-disiloxane (3h) from allylbenzene with 1,1,3,3-tetramethyldisiloxane in the presence of Karstedt's catalyst is representative.

The Solution of allylbenzene $(1.2 \mathrm{ml}, 9.1 \mathrm{mmol})$ and Karstedt's catalyst $(0.3 \mu \mathrm{l}$ of a $0.336 \mathrm{~mol} / \mathrm{l}$ solution of $\mathrm{Pt} / \mathrm{mole}$ of olefin) in toluene $(5 \mathrm{ml})$ was warmed to $40^{\circ} \mathrm{C}$ under argon. 1,1,3,3-tetramethyldisiloxane $(0.72 \mathrm{ml}, 4.13 \mathrm{mmol})$ was added slowly and subsequently heated at To this stirred solution which was subsequently heated at $40^{\circ} \mathrm{C}$ for $3 \mathrm{~h}$. the hydrosilylation was followed by ${ }^{1} \mathrm{H} \mathrm{NMR}$ and the reaction stopped once the $\mathrm{Si}-\mathrm{H}$ signal has disappeared. The solvent was then evaporated under reduced pressure. Volatile by-products and excess of olefin were removed by bulb to bulb distillation $\left(100^{\circ} \mathrm{C}, 0.01\right.$ torr). 1,3-di-(3-(phenyl)propyl)-1,1,3,3-tetramethyl-disiloxane was obtained as viscous oil in a $72 \%$ yields.

d) Preparation of 1,3-di-(3-(phenyl)propyl)-1,1,3,3-tetramethyl-disiloxane (3h) from allylbenzene with 1,1,3,3-tetramethyldisiloxane in the presence of platinum black is representative.

A solution of allylbenzene $(1.2 \mathrm{ml}, 9.1 \mathrm{mmol})$ and platinum black $(0.244 \mathrm{~g}, 1 \times$ $10^{-3} \mathrm{~mole}$ of $\mathrm{Pt} / \mathrm{mole}$ of olefin) in toluene $(5 \mathrm{ml})$ was warmed to $40^{\circ} \mathrm{C}$. To this stirred solution, 1,1,3,3-tetramethyldisiloxane $(0.72 \mathrm{ml}, 4.13 \mathrm{mmol})$ was added slowly and subsequently heated at $40^{\circ} \mathrm{C}$ for $3 \mathrm{~h}$. After filtration over glass wool, the solvent was evaporated under reduced pressure; volatile by-products and excess of olefin were removed by bulb to bulb distillation $\left(100^{\circ} \mathrm{C}, 0.01\right.$ torr).

e) Preparation of 1,1,1,3,5,5,5-heptamethyl-3-(3-phenylpropyl)trisiloxane (3i) from allylbenzene with $M D^{H} M$ in the presence of Karstedt's catalyst is representative.

The solution of allylbenzene $(1.2 \mathrm{ml}, 9.1 \mathrm{mmol})$ and Karstedt's catalyst $(0.3 \mu \mathrm{l}$ of a $0.336 \mathrm{~mol} / \mathrm{l}$ solution of $\mathrm{Pt} / \mathrm{mole}$ of olefin) in toluene $(2.5 \mathrm{ml})$ was warmed to $40^{\circ} \mathrm{C}$ under argon. To this stirred solution $\mathrm{MD}^{\mathrm{H}} \mathrm{M}(3 \mathrm{ml}, 10.92 \mathrm{mmol})$ was added slowly and subsequently heated at $40^{\circ} \mathrm{C}$ for $2 \mathrm{~h}$. The end of the hydrosilylation reactions was determined by the disappearance of the Si-H chemical shift in the ${ }^{1} \mathrm{H}$ NMR spectrum. The solvent and volatile by-products were removed under reduced pressure. Further the product was purified by distillation $\left(70^{\circ} \mathrm{C}, 0.05\right.$ torr) and recovered as a colorless oil in a $90 \%$ yield.

f) Preparation of 1,1,1,3,5,5,5-heptamethyl-3-(3-phenylpropyl)trisiloxane (3i) from allylbenzene with $M D^{\mathrm{H}} \mathrm{M}$ in the presence of platinum black is representative.

A solution of allylbenzene $(1.2 \mathrm{ml}, 9.1 \mathrm{mmol})$ and platinum black $(0.244 \mathrm{~g}, 1 \times$ $10^{-3} \mathrm{~mole}$ of $\mathrm{Pt} / \mathrm{mole}$ of olefin) in toluene $(2.5 \mathrm{ml})$ were warmed up to $40^{\circ} \mathrm{C}$ under argon. To this stirred solution $\mathrm{MD}^{\mathrm{H}} \mathrm{M}(3 \mathrm{ml}, 10.92 \mathrm{mmol})$ was added slowly and subsequently heated at $40^{\circ} \mathrm{C}$ for $2 \mathrm{~h}$. After filtration over glass wool, the sol- 
vent and volatile by-products were removed under reduced pressure. The product was purified by distillation and recovered as a colorless oil.

(3a) yield $=96 \%$ for Karstedt, $94 \%$ for Platinum black. ${ }^{1} \mathrm{H}$ NMR $(500 \mathrm{MHz}$, $\left.\mathrm{CDCl}_{3}\right): \delta 0.09-0.14\left(\mathrm{~m}, 12 \mathrm{H}, \mathrm{Si}-\mathrm{CH}_{3}\right), 0.60\left(\mathrm{t}, \mathrm{J}=11.46 \mathrm{~Hz}, 8 \mathrm{H}, \mathrm{Si}-\mathrm{CH}_{2}\right), 1.65-$ $1.76\left(\mathrm{~m}, 8 \mathrm{H}, \mathrm{Si}-\mathrm{CH}_{2}-\mathrm{CH}_{2}\right), 2.60-2.70\left(\mathrm{~m}, 8 \mathrm{H}, \mathrm{CH}_{2}-\mathrm{Ph}\right), 7.19-7.36(\mathrm{~m}, 20 \mathrm{H}$, $\mathrm{CH}-\mathrm{Ar}) ;{ }^{13} \mathrm{C}$ NMR $\left(125 \mathrm{MHz}, \mathrm{CDCl}_{3}\right): \delta-0.52\left(\mathrm{Si}-\mathrm{CH}_{3}\right), 17.03\left(\mathrm{Si}-\mathrm{CH}_{2}\right), 25.15$ ( $\left.\mathrm{Si}-\mathrm{CH}_{2}-\mathrm{CH}_{2}\right), 39.40\left(\mathrm{CH}_{2}-\mathrm{Ph}\right), 125.73,128.33,128.56$ (CH-Ar), 142.66 (C-Ar); ${ }^{29} \mathrm{Si}$ NMR: $\delta-20.53,-20.46,-20.43$; HRMS Calcd for $\left(\mathrm{C}_{40} \mathrm{H}_{56} \mathrm{O}_{4} \mathrm{Si}_{4}\right)[\mathrm{M}+]$ : 709.3256, Found: 709.3278 .
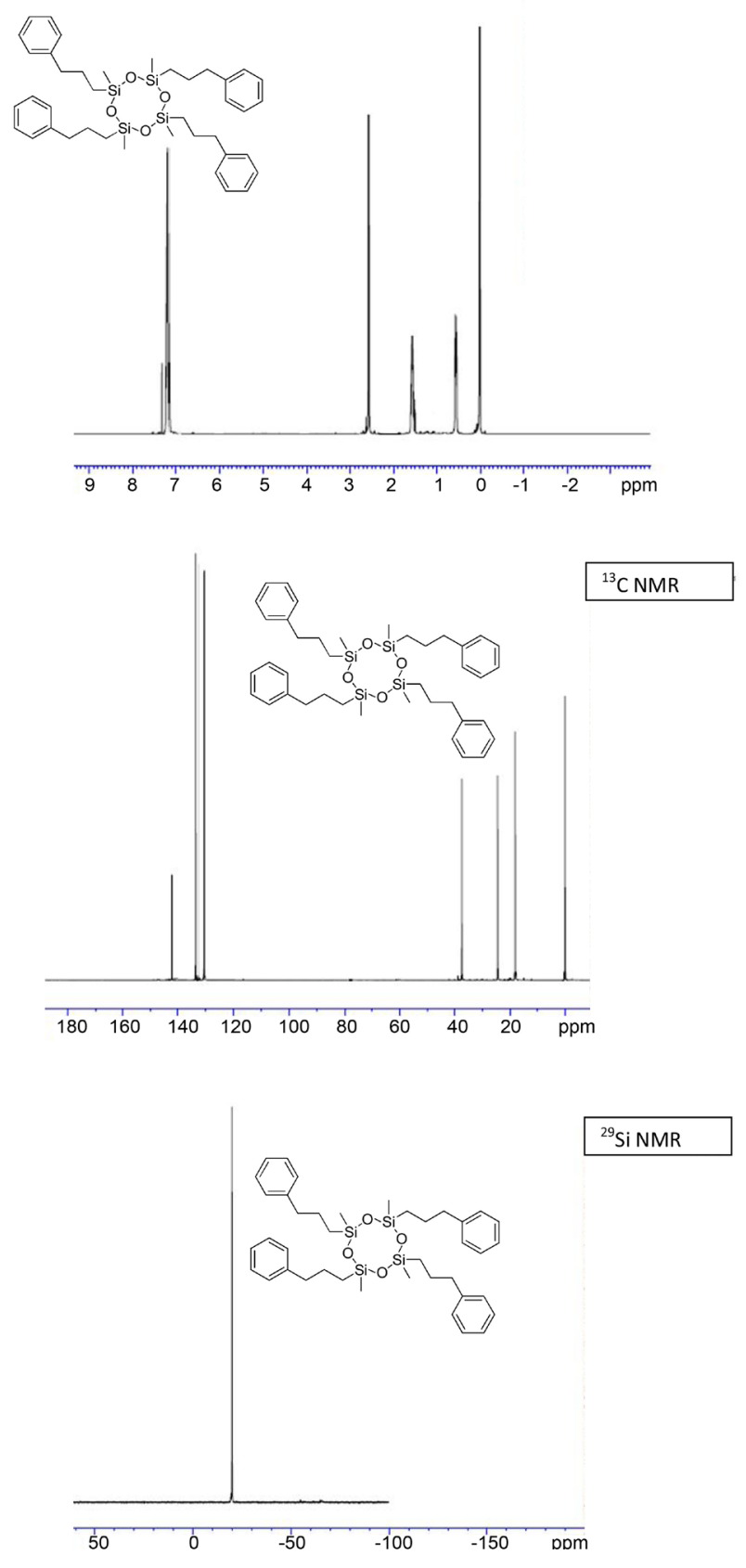
(3b) yield $=94 \%$ for Karstedt, $88 \%$ for Platinum black. ${ }^{1} \mathrm{H}$ NMR $(500 \mathrm{MHz}$, $\left.\mathrm{CDCl}_{3}\right): \delta 0.01\left(\mathrm{~s}, 12 \mathrm{H}, \mathrm{Si}-\mathrm{CH}_{3}\right), 0.55-0.61\left(\mathrm{t}, \mathrm{J}=3.5 \mathrm{~Hz}, 8 \mathrm{H}, \mathrm{Si}-\mathrm{CH}_{2}\right), 1.41-1.59$ (m, 8H, Si- $\left.\mathrm{CH}_{2}-\mathrm{CH}_{2}\right), 2.26$ (s, 12H, $\left.\mathrm{CH}_{3}-\mathrm{Ph}\right), 2.51-2.59$ (m, 8H, $\left.\mathrm{CH}_{2}-\mathrm{Ph}\right), 7.00$ $7.22(\mathrm{~m}, 16 \mathrm{H}, \mathrm{CH}-\mathrm{Ar}) ;{ }^{13} \mathrm{C} \mathrm{NMR}\left(125 \mathrm{MHz}, \mathrm{CDCl}_{3}\right): \delta-0.64\left(\mathrm{Si}_{-} \mathrm{CH}_{3}\right), 17.88$ (Si-CH 2$), 19.89\left(\mathrm{CH}_{3}-\mathrm{Ph}\right), 24.39\left(\mathrm{Si}-\mathrm{CH}_{2}-\mathrm{CH}_{2}\right), 37.41\left(\mathrm{CH}_{2}-\mathrm{Ph}\right), 126.44,129.52$, 130.73 (CH-Ar), 136.46, 141.45 (C-Ar); ${ }^{29} \mathrm{Si}$ NMR: $\delta-20.12,-20.08$; HRMS Calcd for $\left.\left(\mathrm{C}_{44} \mathrm{H}_{64} \mathrm{O}_{4} \mathrm{Si}_{4}\right)\right)[\mathrm{M}+]$ : 769.3241, Found: 769.3245.
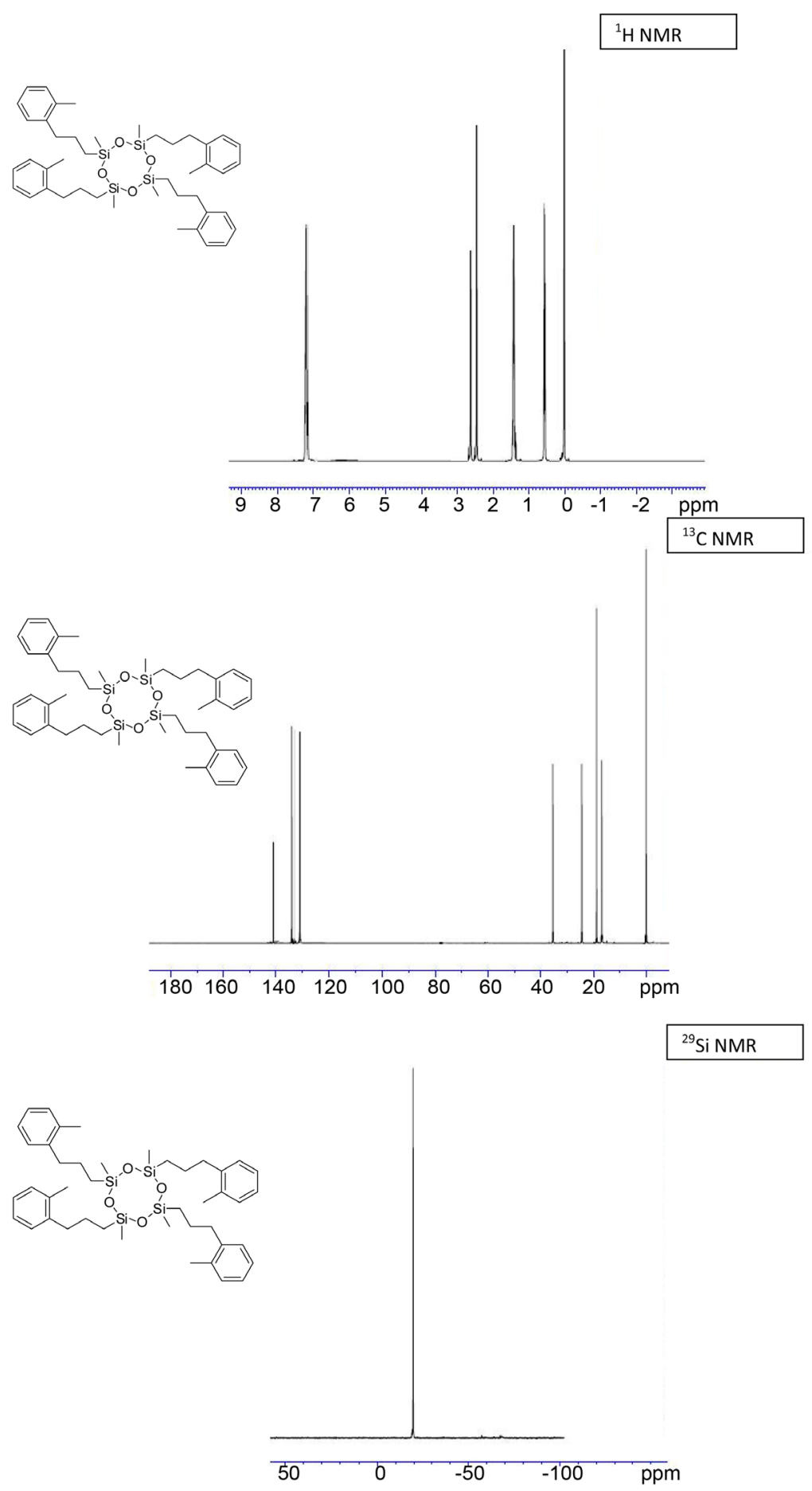
(3c) yield $=95 \%$ for Karstedt, $89 \%$ for Platinum black. ${ }^{1} \mathrm{H}$ NMR $(500 \mathrm{MHz}$, $\left.\mathrm{CDCl}_{3}\right): \delta 0.04\left(\mathrm{~s}, 12 \mathrm{H}, \mathrm{Si}-\mathrm{CH}_{3}\right), 0.61-0.68\left(\mathrm{t}, \mathrm{J}=13.5 \mathrm{~Hz}, 8 \mathrm{H}, \mathrm{Si}-\mathrm{CH}_{2}\right), 1.42-$ 1.53 (s, 8H, Si- $\left.\mathrm{CH}_{2}-\mathrm{CH}_{2}\right), 2.30$ (s, $\left.12 \mathrm{H}, \mathrm{CH}_{3}-\mathrm{Ph}\right), 2.59-2.68\left(\mathrm{~m}, 8 \mathrm{H}, \mathrm{CH}_{2}-\mathrm{Ph}\right.$ ), $7.01-7.46(\mathrm{~m}, 16 \mathrm{H}, \mathrm{CH}-\mathrm{Ar}) ;{ }^{13} \mathrm{C}$ NMR $\left(125 \mathrm{MHz}, \mathrm{CDCl}_{3}\right): \delta-0.01\left(\mathrm{Si}_{-} \mathrm{CH}_{3}\right)$, $18.03\left(\mathrm{Si}-\mathrm{CH}_{2}\right), 19.72\left(\mathrm{CH}_{3}-\mathrm{Ph}\right), 22.12\left(\mathrm{Si}-\mathrm{CH}_{2}-\mathrm{CH}_{2}\right), 34.63\left(\mathrm{CH}_{2}-\mathrm{Ph}\right), 126.15$, 127.55, 128.92 (CH-Ar), 131.70, 137.53 (C-Ar); ${ }^{29} \mathrm{Si}$ NMR: $\delta-20.11,-20.06$; HRMS Calcd for $\left.\left(\mathrm{C}_{44} \mathrm{H}_{64} \mathrm{O}_{4} \mathrm{Si}_{4}\right)\right)$ [M+]: 769.3242, Found: 769.3248 .
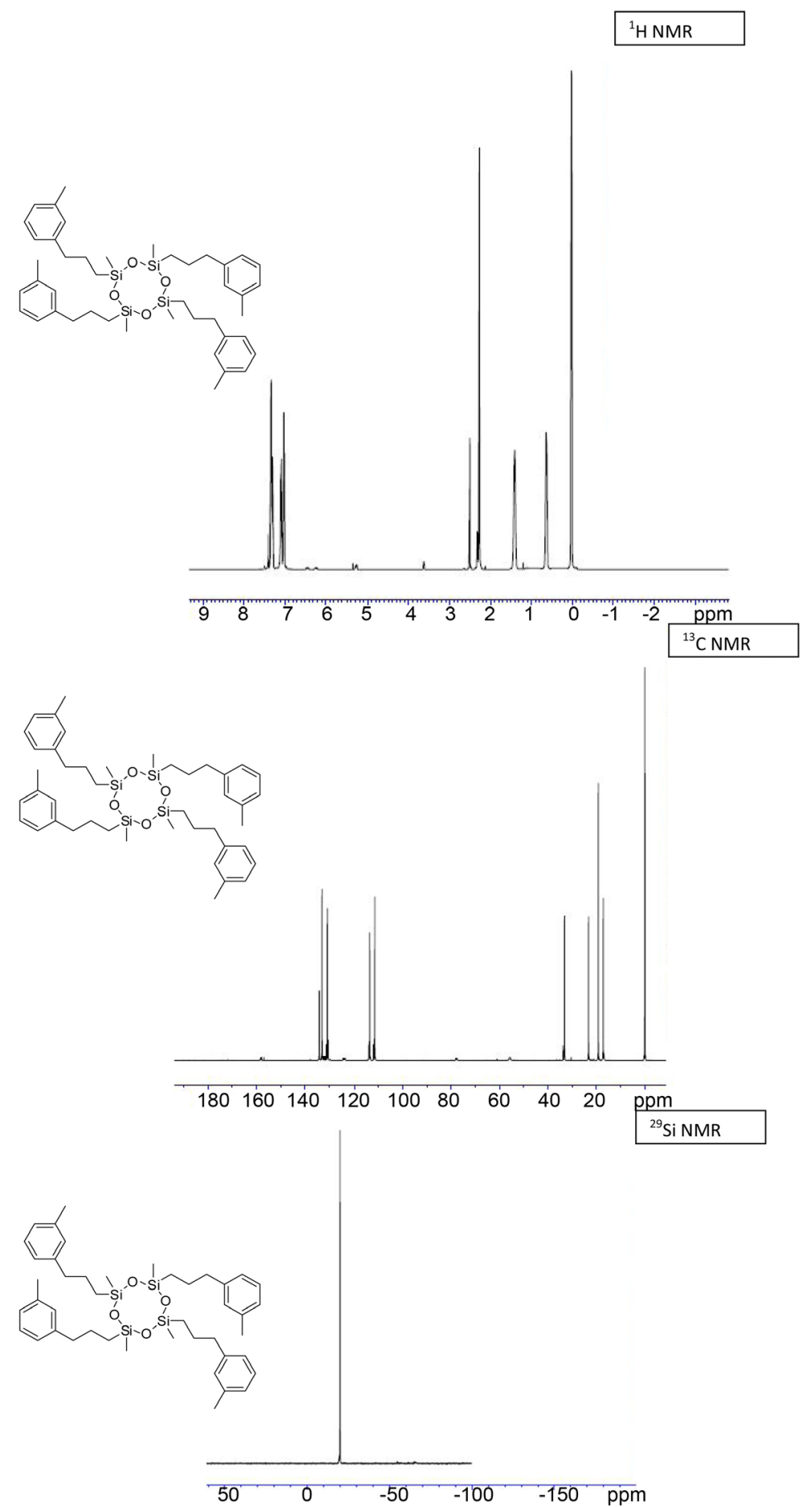
(3d) yield $=98 \%$ for Karstedt, $85 \%$ for Platinum black. ${ }^{1} \mathrm{H}$ NMR $(500 \mathrm{MHz}$, $\left.\mathrm{CDCl}_{3}\right): \delta 0.01\left(\mathrm{~s}, 12 \mathrm{H}, \mathrm{Si}-\mathrm{CH}_{3}\right), 0.62-0.69\left(\mathrm{t}, \mathrm{J}=10 \mathrm{~Hz}, 8 \mathrm{H}, \mathrm{Si}-\mathrm{CH}_{2}\right), 1.40-1.49$ (m, 8H, Si- $\left.\mathrm{CH}_{2}-\mathrm{CH}_{2}\right), 2.54\left(\mathrm{~m}, 12 \mathrm{H}, \mathrm{CH}_{3}-\mathrm{Ph}\right), 2.60\left(\mathrm{~m}, 8 \mathrm{H}, \mathrm{CH}_{2}-\mathrm{Ph}\right), 7.00-7.12$ $(\mathrm{m}, 16 \mathrm{H}, \mathrm{CH}-\mathrm{Ar}) ;{ }^{13} \mathrm{C} \mathrm{NMR}\left(125 \mathrm{MHz}, \mathrm{CDCl}_{3}\right): \delta-0.00\left(\mathrm{Si}_{-} \mathrm{CH}_{3}\right), 18.01$ $\left(\mathrm{Si}-\mathrm{CH}_{2}\right), 19.61\left(\mathrm{CH}_{3}-\mathrm{Ph}\right), 22.08\left(\mathrm{Si}-\mathrm{CH}_{2}-\mathrm{CH}_{2}\right), 34.12\left(\mathrm{CH}_{2}-\mathrm{Ph}\right), 127.36,127.98$, 128.13 (CH-Ar), 136.65, 136.74 (C-Ar); ${ }^{29} \mathrm{Si}$ NMR: $\delta-21.87$; HRMS Calcd for $\left.\left(\mathrm{C}_{44} \mathrm{H}_{64} \mathrm{O}_{4} \mathrm{Si}_{4}\right)\right)[\mathrm{M}+]$ : 769.3246, Found: 769.3253 .
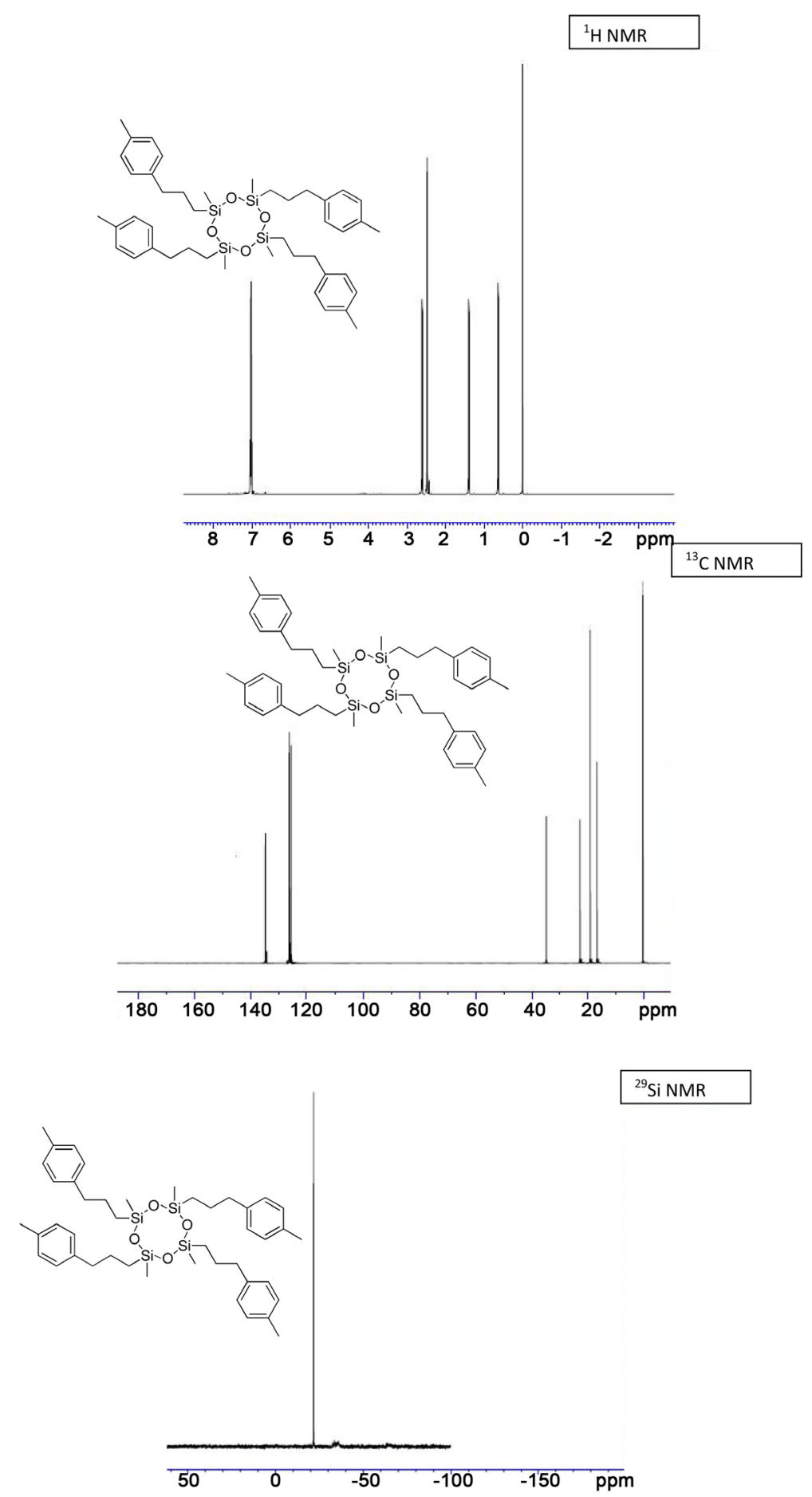
(3e) yield $=53 \%$ for Karstedt, $49 \%$ for Platinum black. ${ }^{1} \mathrm{H}$ NMR $(500 \mathrm{MHz}$, $\left.\mathrm{CDCl}_{3}\right): \delta 0.02\left(\mathrm{~s}, 12 \mathrm{H}, \mathrm{Si}-\mathrm{CH}_{3}\right), 0.51\left(\mathrm{t}, \mathrm{J}=5 \mathrm{~Hz}, 8 \mathrm{H}, \mathrm{Si}-\mathrm{CH}_{2}\right), 1.52(\mathrm{~s}, 8 \mathrm{H}$, $\left.\mathrm{Si}-\mathrm{CH}_{2}-\mathrm{CH}_{2}\right), 2.22-2.31\left(\mathrm{~m}, 8 \mathrm{H}, \mathrm{CH}_{2}-\mathrm{Ph}\right), 2.45-2.56\left(\mathrm{~s}, 12 \mathrm{H}, \mathrm{CH}_{3}-\mathrm{O}\right), 7.02-$ $7.22(\mathrm{~m}, 16 \mathrm{H}, \mathrm{CH}-\mathrm{Ar}) ;{ }^{13} \mathrm{C} \mathrm{NMR}\left(125 \mathrm{MHz}, \mathrm{CDCl}_{3}\right): \delta-0.00\left(\mathrm{Si}_{-} \mathrm{CH}_{3}\right), 17.61$ $\left(\mathrm{Si}-\mathrm{CH}_{2}\right), 22.05\left(\mathrm{Si}-\mathrm{CH}_{2}-\mathrm{CH}_{2}\right), 25.65\left(\mathrm{CH}_{2}-\mathrm{Ph}\right), 39.94\left(\mathrm{CH}_{3}-\mathrm{O}\right), 116.30,125.93$, 128.75, 129.92 (CH-Ar), 138.48, 143.17 (C-Ar); ${ }^{29} \mathrm{Si}$ NMR: $\delta-20.87$; HRMS Calcd for $\left.\left(\mathrm{C}_{44} \mathrm{H}_{64} \mathrm{O}_{8} \mathrm{Si}_{4}\right)\right)[\mathrm{M}+]$ : 833.3266, Found: 833.3278.
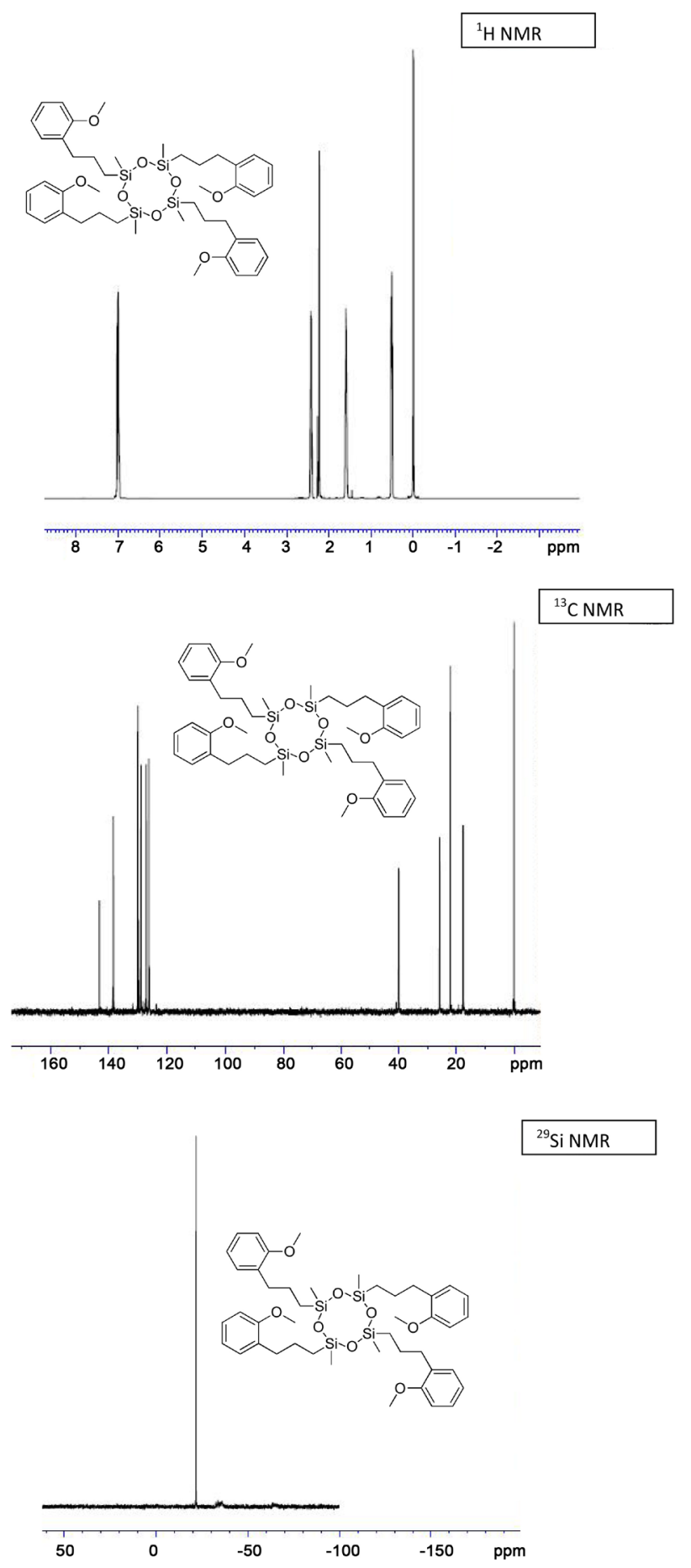
(3f) yield $=50 \%$ for Karstedt, $46 \%$ for Platinum black. ${ }^{1} \mathrm{H}$ NMR $(500 \mathrm{MHz}$, $\left.\mathrm{CDCl}_{3}\right): \delta 0.12\left(\mathrm{~s}, 12 \mathrm{H}, \mathrm{Si}-\mathrm{CH}_{3}\right), 0.73\left(\mathrm{t}, \mathrm{J}=4.5 \mathrm{~Hz}, 8 \mathrm{H}, \mathrm{Si}-\mathrm{CH}_{2}\right), 1.70(\mathrm{~m}, 8 \mathrm{H}$, $\left.\mathrm{Si}-\mathrm{CH}_{2}-\mathrm{CH}_{2}\right), 2.59-2.61\left(\mathrm{~m}, 8 \mathrm{H}, \mathrm{CH}_{2}-\mathrm{Ph}\right), 7.15-7.38$ (m, $\left.16 \mathrm{H}, \mathrm{CH}-\mathrm{Ar}\right) ;{ }^{13} \mathrm{C}$ $\operatorname{NMR}\left(125 \mathrm{MHz}, \mathrm{CDCl}_{3}\right): \delta-0.61\left(\mathrm{Si}-\mathrm{CH}_{3}\right), 19.81\left(\mathrm{Si}-\mathrm{CH}_{2}\right), 23.46\left(\mathrm{Si}-\mathrm{CH}_{2}-\mathrm{CH}_{2}\right)$, $28.36\left(\mathrm{CH}_{2}-\mathrm{Ph}\right), 115.54\left(\mathrm{C}-\mathrm{F}_{3}\right), 125.30,128.48$ (CH-Ar), 136.33, 144.16 (C-Ar); ${ }^{29} \mathrm{Si}$ NMR: $\delta$-22.06; HRMS Calcd for $\left.\left(\mathrm{C}_{44} \mathrm{H}_{52} \mathrm{~F}_{12} \mathrm{O}_{4} \mathrm{Si}_{4}\right)\right)[\mathrm{M}+]$ : 985.2032, Found: 985.2045.
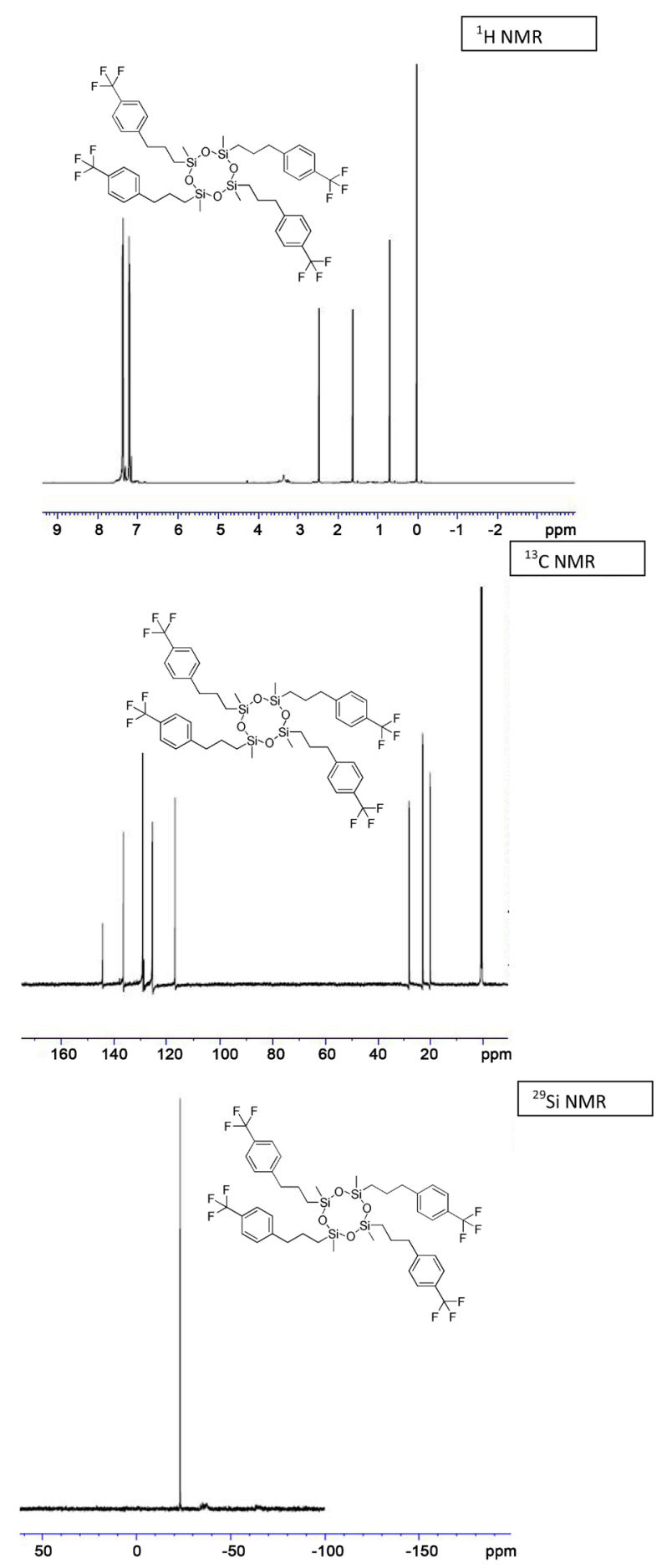
(3g) yield $=52 \%$ for Karstedt, $47 \%$ for Platinum black. ${ }^{1} \mathrm{H}$ NMR $(500 \mathrm{MHz}$, $\left.\mathrm{CDCl}_{3}\right): \delta 0.14\left(\mathrm{~s}, 12 \mathrm{H}, \mathrm{Si}-\mathrm{CH}_{3}\right), 0.59\left(\mathrm{t}, \mathrm{J}=2.5 \mathrm{~Hz}, 8 \mathrm{H}, \mathrm{Si}_{-} \mathrm{CH}_{2}\right), 1.65(\mathrm{~s}, 8 \mathrm{H}$, $\left.\mathrm{Si}-\mathrm{CH}_{2}-\mathrm{CH}_{2}\right), 2.58-2.63\left(\mathrm{~m}, 8 \mathrm{H}, \mathrm{CH}_{2}-\mathrm{Ph}\right), 7.05-7.51$ (m, $\left.16 \mathrm{H}, \mathrm{CH}-\mathrm{Ar}\right) ;{ }^{13} \mathrm{C}$ NMR (125 MHz, $\left.\mathrm{CDCl}_{3}\right): \delta-0.68\left(\mathrm{Si}-\mathrm{CH}_{3}\right), 19.72\left(\mathrm{Si}-\mathrm{CH}_{2}\right), 23.61\left(\mathrm{Si}-\mathrm{CH}_{2}-\mathrm{CH}_{2}\right)$, $28.80\left(\mathrm{CH}_{2}-\mathrm{Ph}\right), 126.82$ (C-Br), 127.01, 129.46, 129.60 (CH-Ar), 131.82, 134.68 (C-Ar); ${ }^{29} \mathrm{Si}$ NMR: $\delta-23.29,-24.64$; HRMS Calcd for $\left.\left(\mathrm{C}_{40} \mathrm{H}_{52} \mathrm{Br}_{4} \mathrm{O}_{4} \mathrm{Si}_{4}\right)\right)[\mathrm{M}+]$ : 1028.8021, Found: 1028.8067 .
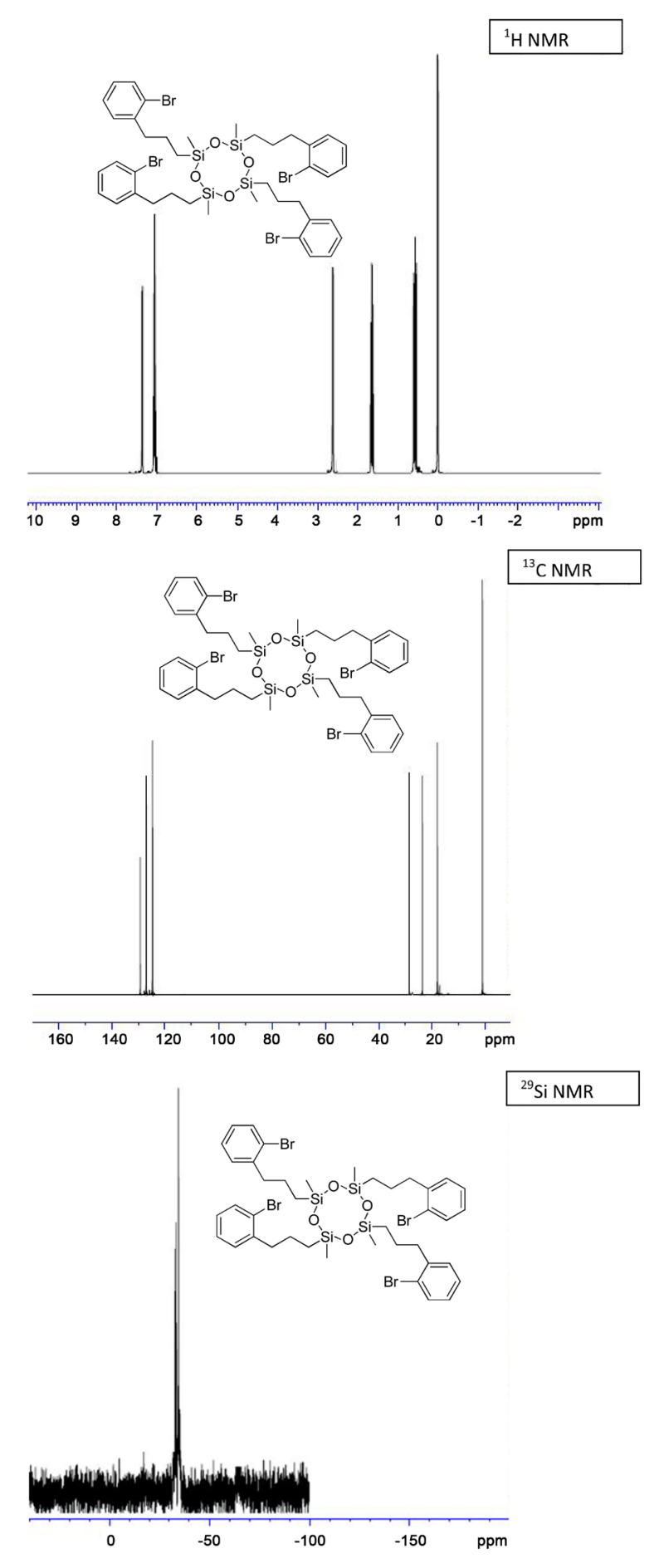
(3h) yield $=72 \%$ for Karstedt, $71 \%$ for Platinum black. ${ }^{1} \mathrm{H}$ NMR $(500 \mathrm{MHz}$, $\left.\mathrm{CDCl}_{3}\right): \delta 0.00\left(\mathrm{~s}, 6 \mathrm{H}, \mathrm{Si}-\mathrm{CH}_{3}\right), 0.61\left(\mathrm{t}, \mathrm{J}=9.41 \mathrm{~Hz}, 4 \mathrm{H}, \mathrm{Si}-\mathrm{CH}_{2}\right), 1.58(\mathrm{~m}, 4 \mathrm{H}$, $\mathrm{Si}-\mathrm{CH}_{2}-\mathrm{CH}_{2}$ ), 2.61 (m, 4H, CH$-\mathrm{Ph}$ ), $7.01-7.39$ (m, 10H, CH-Ar); ${ }^{13} \mathrm{C}$ NMR (125 $\left.\mathrm{MHz}, \mathrm{CDCl}_{3}\right): \delta-0.22\left(\mathrm{Si}-\mathrm{CH}_{3}\right), 20.75\left(\mathrm{Si}-\mathrm{CH}_{2}\right), 22.02\left(\mathrm{Si}-\mathrm{CH}_{2}-\mathrm{CH}_{2}\right), 29.66$ $\left(\mathrm{CH}_{2}-\mathrm{Ph}\right), 125.73,128.33,128.56$ (CH-Ar), 142.66 (C-Ar); ${ }^{29} \mathrm{Si} \mathrm{NMR}: \delta-22.87$; HRMS Calcd for $\left.\left(\mathrm{C}_{22} \mathrm{H}_{34} \mathrm{OSi}_{2}\right)\right)$ [M+]: 370.6878, Found: 370.6889 .

${ }^{1}$ H NMR
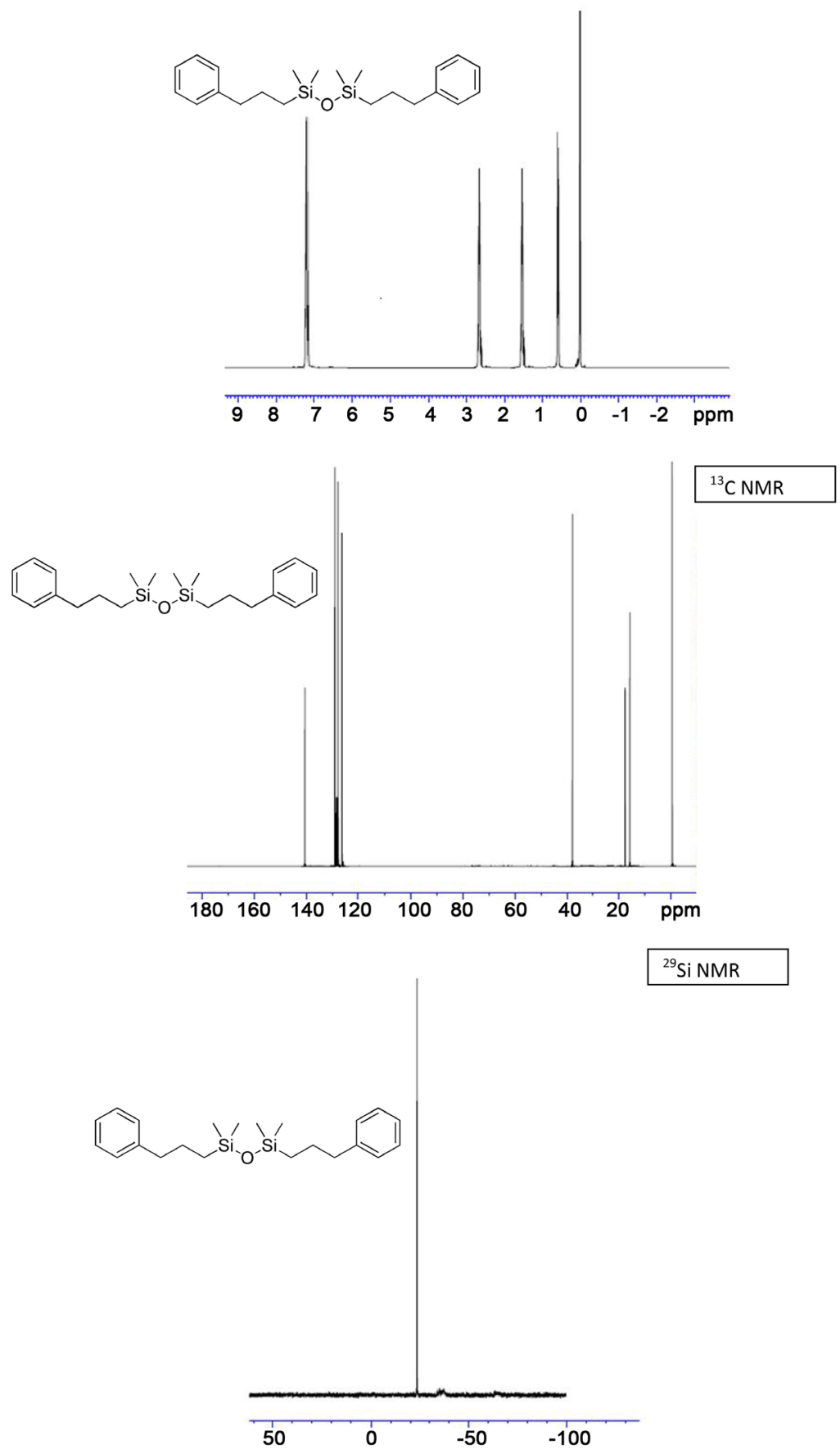
(3i) yield $=90 \%$ for Karstedt, $87 \%$ for Platinum black. ${ }^{1} \mathrm{H}$ NMR $(500 \mathrm{MHz}$, $\mathrm{CDCl} 3): \delta 0.01\left(\mathrm{~m}, 18 \mathrm{H}, \mathrm{Si}-\left(\mathrm{CH}_{3}\right)_{3}\right), 0.14\left(\mathrm{~s}, 3 \mathrm{H}, \mathrm{Si}-\mathrm{CH}_{3}\right), 0.61(\mathrm{t}, \mathrm{J}=10.46 \mathrm{~Hz}$, $\left.2 \mathrm{H}, \mathrm{Si}-\mathrm{CH}_{2}\right), 1.58\left(\mathrm{~m}, 2 \mathrm{H}, \mathrm{Si}-\mathrm{CH}_{2}-\mathrm{CH}_{2}\right), 2.60-2.70\left(\mathrm{~m}, 2 \mathrm{H}, \mathrm{CH}_{2}-\mathrm{Ph}\right), 7.20-7.26$ $(\mathrm{m}, 5 \mathrm{H}, \mathrm{CH}-\mathrm{Ar}) ;{ }^{13} \mathrm{C}$ NMR (125 MHz, CDCl3): $\delta-3.77\left(\mathrm{Si}-\mathrm{CH}_{3}\right), 0.33$ $\left(\mathrm{Si}-\left(\mathrm{CH}_{3}\right)_{3}\right), 20.83\left(\mathrm{Si}-\mathrm{CH}_{2}\right), 25.46\left(\mathrm{Si}-\mathrm{CH}_{2}-\mathrm{CH}_{2}\right), 35.66\left(\mathrm{CH}_{2}-\mathrm{Ph}\right), 125.98,128.39$, 128.44 (CH-Ar), 142.52 (C-Ar); ${ }^{29} \mathrm{Si}$ NMR: $\delta-21.19\left(\mathrm{Si}-\mathrm{CH}_{3}\right), 6.81\left(\mathrm{Si}-\left(\mathrm{CH}_{3}\right)_{3}\right)$; HRMS Calcd for $\left(\mathrm{C}_{16} \mathrm{H}_{32} \mathrm{O}_{2} \mathrm{Si}_{3}\right)[\mathrm{M}+]$ : 340.6858 , Found: 340.5423 .
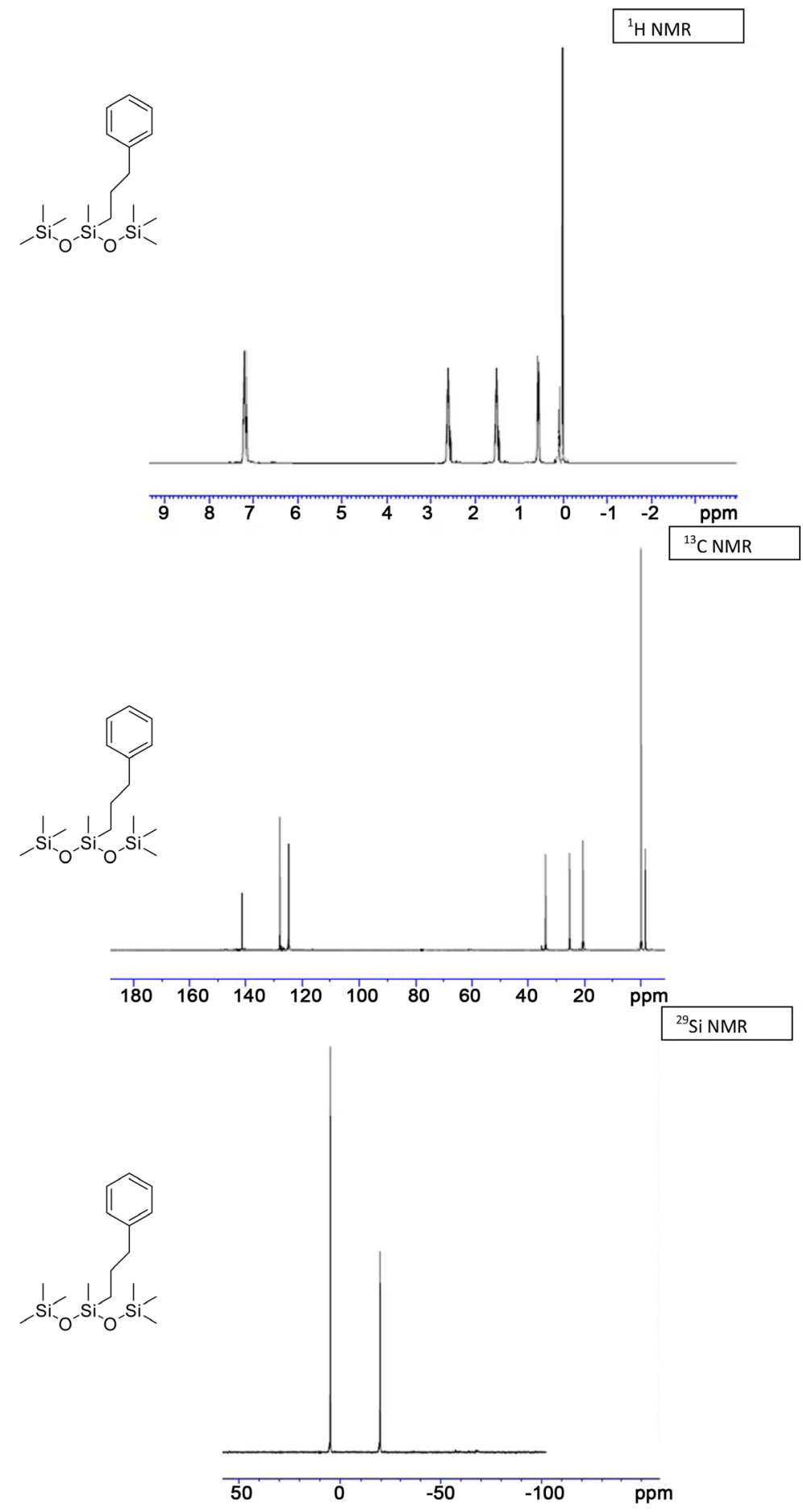


\section{Conflicts of Interest}

The authors declare no conflicts of interest regarding the publication of this paper.

\section{References}

[1] Kendrick, T.C., Parbhoo, B. and White, J.W. (1989) Chemistry of Organic Silicon Compounds. In: Patai, S. and Rappaport, Z., Eds., Chapter 21, John Wiley \& Sons, Chichester.

[2] Chojnowsky, J. (1993) Siloxane Polymers. In: Clarson, S.J. and Semlyen, J.A., Eds., Englewood Cliffs, Prentice Hall, NJ, 1.

[3] Saam, J.C. (1990) In Silicon Based Polymer Science. In: Zeigler, J.M. and Gordon Fearon, F.W., Eds., Advances in Chemistry Series 224, American Chemical Society, Washington, DC.

[4] Ojima, I. (1989) Chemistry of Organic Silicon Compounds. In: Patai, S. and Rappaport, Z., Eds., Chapter 25, John Wiley \& Sons, Chichester.

[5] Yoshii, E., Kobayashi, Y., Koizumi, T. and Oribe, T. (1974) Hydrosilation of Unsaturated Esters. Chemical and Pharmaceutical Bulletin, 22, 2767-2769.

[6] Ryan, J.W. and Speier, L. (1964) The Addition of Silicon Hydrides to Olefinic Double Bonds. VIII. The Addition of Trichlorosilane-d. Journal of the American Chemical Society, 86, 895-898.

[7] Speier, J.L., Webster, J.A. and Barnes, G.H. (1957) The Addition of Silicon Hydrides to Olefinic Double Bonds. Part II. The Use of Group VIII Metal Catalysts. Journal of the American Chemical Society, 79, 974-979. https://doi.org/10.1021/ja01561a054

[8] Lewis, L.N. and Lewis, N.J. (1986) Platinum-Catalyzed Hydrosilylation Colloid Formation as the Essential Step. Journal of the American Chemical Society, 108, 7228. https://doi.org/10.1021/ja00283a016

[9] Zhang, C.R. and Laine, M.J. (2000) Hydrosilylation of Allyl Alcohol with [HSiMe2OSiO1.5]8: Octa(3-Hydroxypropyldimethylsiloxy)octasilsesquioxane and Its Octamethacrylate Derivative as Potential Precursors to Hybrid Nanocomposites. Journal of the American Chemical Society 122, 6979-6988. https://doi.org/10.1021/ja000318r

[10] El Malki, Hannioui, A., Rakib, E.M., Knouzi, N. and Vaultier, M. (2011) Regioselective Platinum Catalyzed-Hydrosilylation of Allylic Benzene Derivatives with Cyclic Siloxane $\mathrm{D}_{4}{ }^{\mathrm{H}}$. Letters in Organic Chemistry, 8, 361-363. https://doi.org/10.2174/157017811795684992

[11] Igarashi, M., Matsumoto, T., Kobayashi, T., Sato, K., Ando, W., Shimada, S., Hara, M. and Uchida, H. (2014) Hydrosilylation of Allyl Derivatives with T, D and M Type Hydrosilanes. Journal of Organometallic Chemistry, 749, 421-427. https://doi.org/10.1016/j.jorganchem.2013.10.014

[12] Yang, X.L., Bai, Y., Li, J.Y., Dai, Z.N. and Peng, J.J. (2019) Hydrosilylation of Alkenes Catalyzed by Fe Powder. Phosphorus, Sulfur, and Silicon and the Related Elements, 194, 1-4. https://doi.org/10.1080/10426507.2018.1506782 